
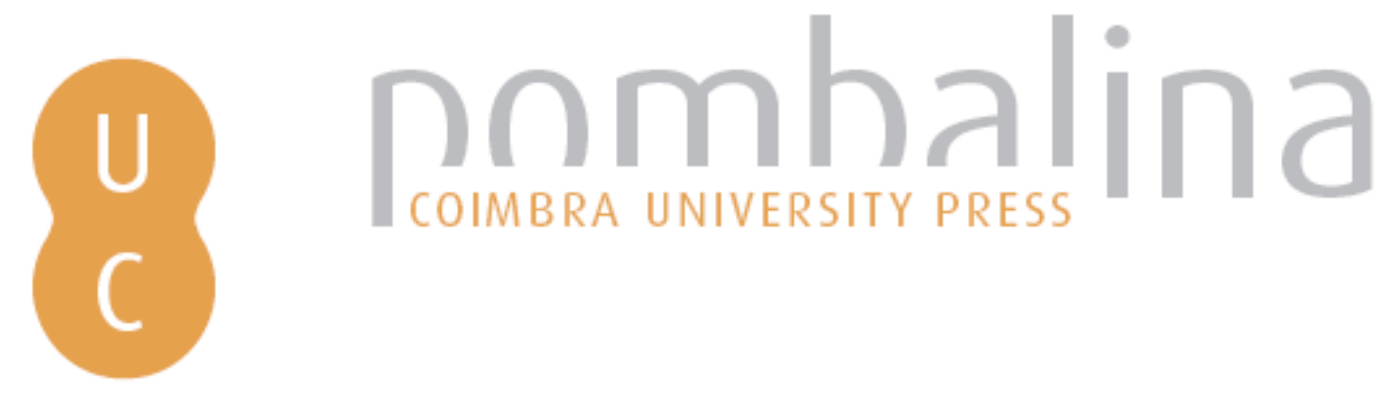

\title{
The influence of Bologna process and Lisbon strategy on the rhetoric change in government' programs in Portugal
}

\author{
Autor(es): $\quad$ Lameiras, Jorge \\ Publicado por: Imprensa da Universidade de Coimbra \\ URL \\ persistente: URI:http://hdl.handle.net/10316.2/46344 \\ DOI: $\quad$ DOl:https://doi.org/10.14195/978-989-26-1620-9_5 \\ Accessed : $\quad$ 26-Apr-2023 10:34:46
}

A navegação consulta e descarregamento dos títulos inseridos nas Bibliotecas Digitais UC Digitalis, UC Pombalina e UC Impactum, pressupõem a aceitação plena e sem reservas dos Termos e Condições de Uso destas Bibliotecas Digitais, disponíveis em https://digitalis.uc.pt/pt-pt/termos.

Conforme exposto nos referidos Termos e Condições de Uso, o descarregamento de títulos de acesso restrito requer uma licença válida de autorização devendo o utilizador aceder ao(s) documento(s) a partir de um endereço de IP da instituição detentora da supramencionada licença.

Ao utilizador é apenas permitido o descarregamento para uso pessoal, pelo que o emprego do(s) título(s) descarregado(s) para outro fim, designadamente comercial, carece de autorização do respetivo autor ou editor da obra.

Na medida em que todas as obras da UC Digitalis se encontram protegidas pelo Código do Direito de Autor e Direitos Conexos e demais legislação aplicável, toda a cópia, parcial ou total, deste documento, nos casos em que é legalmente admitida, deverá conter ou fazer-se acompanhar por este aviso.

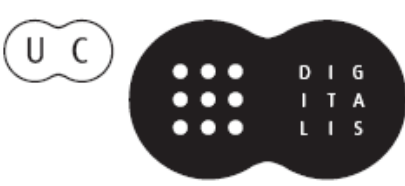


Cristina Pinto Albuquerque Ana Maria Seixas

Albertina Lima Oliveira

António Gomes Ferreira

Maria Paula Paixão

Rui Paquete Paixão COORDS

\section{HIGHER}

EDUCATION

AFTER

BOLOGNA

Challenges and Perspectives 


\title{
CHAPTER 5
}

\section{THE INFLUENCE OF BOLOGNA PROCESS \\ AND LISBON STRATEGY ON THE RHETORIC CHANGE IN GOVERNMENT' PROGRAMS IN PORTUGAL}

\author{
Jorge Lameiras \\ University of Aveiro (Portugal) \\ Email: jorge.lameiras@ua.pt
}

In 1974 a military Revolution changed the political regime, and opened the Portuguese society to new social, economic and cultural challenges. A reform launched by the old regime in 1973 as a response to a social and economic need to modernize Portuguese society, was adjusted but continued until the full creation of the binary system. This organizational option was adopted for the higher education system to enhance its ability to produce knowledge, to deliver teaching and to give the expected contribution to improve the economy and to raise culture and qualification in society. During all the time, economic issues have been present in discourse about higher education: as the essential issue of funding to assure the sustainability of institutions; as a contributor agent through knowledge transfer to increase productivity and economy. At European 
level the willingness and decision to introduce changes at higher education systems became merged with a European initiative to increase the potential of European economy. In Portugal the Bologna Process triggered a reform of the higher education system, from legal framework to pedagogical methodologies in the classroom, and so is an opportunity to improve quality and deepen the identity of institutions and sectors.

\section{Introduction}

Huntington (1991) describes the evolution of democracy in the modern world through an idea of waves of democratization. The first wave started in 1820 with the widening of suffrage to a large proportion of the male population in the United States of America, and continues until circa 1926. However in 1922 there was a reverse wave associated to the raising of fascist regimes in Europe. The second wave appeared after the World War II until mid-sixties of the XX.th century. A new reverse wave occurred until mid-seventies. But between 1974 and 1990 approximately, a third wave of change brought a new hope and an increase in the number of democratic countries. This wave includes different processes, as external imposition of a regime after a military conflict (Germany and Japan), negotiated changes (Spain) and revolutionary processes (Portugal) (Fernandes, 2014; Huntington, 1991). Reasons for revolutionary change are diverse, including change in political institutions, the quest for better life conditions, and the more equitable distribution of social and economic resources as education (Fernandes, 2014).

The uprising of a neoliberal influence in European political regimes, since the 80 's produced an increasing pressure over higher education institutions to be more effective in providing 
educational services and research, in more volume, more competitive in international grounds and capable to attract funding intended to reduce their dependence from public funding. The idea of a self-regulated and diversified system appeared as a means to make institutions accountable, more innovative, easier to manage, and more efficient in managing the available resources (Zha, 2009).

This chapter presents a perspective about the relation between the changing European context in higher education following the Bologna Declaration (1999) and the Lisbon Strategy (2000), seemingly merged in the form of the Bologna Process, and the change in rhetoric of Portuguese Government Programs. The objective is to assess the match between the rhetoric associated to the Bologna Process and to the Portuguese' Government Programs in matter of higher education. For that, several issues were identified in international documents that represent the origin and monitoring of the Bologna Process, and 27 Government Programs were assessed, from before and after the implementation of the Bologna Process in Portugal.

\section{A brief context in recent political history of Portugal}

In 1910 Portuguese monarchic regime fall giving way to the First Republic. Later, a military coup in 1926 ended the First Republic (Carvalho, 2008) and gave rise to a corporative regime since 1933 with the approval of a new Constitution. Until 1974, Portugal was under a conservative, corporative and authoritarian regime called 'Estado Novo'. This regime was based in ideas as a national union and a social democracy inspired in principles of the Christian social doctrine, a strong but not totalitarian regime and a corporative option as an alternative to capitalism 
and socialism, stating a difference to fascist regimes that share the corporative option (Torgal, 1999).

Under 'Estado Novo' and until the Revolution occurred in 1974 the Portuguese higher education system was a 'university dominated system'. As Scott (1995, p. 37) defines, it was a system «in which any other institutions are seen as part of the secondary, or at the most, technical education sector, and in which the universities and these embryonic post-secondary institutions are regarded as separate sectors". In fact, the Portuguese system could hardly be considered a system at least in the sense of a network of institutions following a diversity of social interests. Instead, there were a few universities pursuing their vision of academic functions of teaching and research.

In the Portuguese Constitution adopted in 1933, University was considered as a corporative entity responsible for scientific, cultural, artistic or physical education objectives. Universities were seen with a corporate rationale of a community of scholars under a common legal framework limiting their general autonomy and submitting their mission to an ideologically driven vision of society (Torgal, 1999). The regime had put university inside the regime as an instrument for culture and to raise the nation leaders (Garrido, 2008).

By 1974 there were only 4 public Universities (Coimbra, created in the XIII.th century, Porto and Lisbon 'classic' in 1911, and Lisbon 'technical' in 1930), 1 public higher education institute (ISCTE, created in 1972) and the Catholic University (formally created in 1967). Beyond those institutions there were some other non-University institutions with a status of high level education, 2 in arts, 1 in physical education, 1 in economic and social studies and 2 military academies. A kind of general alternative to the University was the 'Ensino Médio' a vocational and professionally driven path of education. It was formally 
created by two legal diplomas in 1931 and later considered as a third level after elementary and complimentary professional training (1947, and 1948).

By the beginning of 2016, Portugal had 48 Universities and Polytechnic Institutes, not including delegations, almost three hundred units for teaching and research ('Faculdades' or 'Escolas Superiores'), and another 75 Higher Education Schools not integrated in a University or in a Polytechnic Institute, mainly in the Private sector.

\subsection{Pressure for change and emergence of the binary system}

In the past century, during the sixties, several papers from Portuguese researchers have shown some changes in the society landscape and university internal environment in Portugal. It is important to know how Portuguese research at that time read the social and academic reality.

In a context of high level of illiteracy, between early 50's and middle 60's there was a growth of approximately $68 \%$ in general student population, mostly at elementary level, while the demographic growth were less than $8 \%$ (Martins, 1968). University student population has also grown between middle 50's and late 60's (Cruzeiro, 1970) but university students were a very few percentage of the total student population. In 1978 even after a sudden growth in access following the Revolution of 1974 they represent only $4.4 \%$ of total student population (Pordata, 2016).

Sedas Nunes (1968) consider that University was a promoting factor of entrenchment of social inequality in Portugal. He points three problems. First, the high level of dropout during elementary and secondary level generates an underrepresentation of lower social classes among university' students. Marcelo Caetano (1974) 
the last Prime Minister of the pre-revolution conservative regime in his defense manifesto book mentioned that there were no obstacle to a son of a blue collar man to study at 'liceu' (the post-elementary school) nor to the son of bourgeois to enter at a technical school. And because the elementary technical education give access to 'ensino médio' and this give access to higher education every student in an industrial technical school could continue its studies to become an engineer. This liberal principle of access is recognized by Torgal (1999). Even so, the reality was the advantage of children of upper social classes to reach to the university, comparing to children from lower social classes. There was also an advantage of men comparing to women (Cruzeiro, 1970). The reality reported by Gomes (1964) is a precocious option between middle and technical education resulting later in difficulty to achieve conditions for mobility between academic and professional education. Other suggested explanation is a 'intra-projection' by individuals of the social structures, relations and institutions, strongly enough to condition educational and professional choices (Nunes, 1970).

The second problem is the inadequacy of the structure and functional organization of the university to the demand. It included structural insufficiency, programs too long without intermediate degrees, the excessive theoretical character of courses lacking pedagogical innovation, and high dropout level. Beyond the pre-access selectivity or scholarly aptitudes many students face insufficient economic resources to cope with the duration and cost-benefit of programs (Nunes, 1968). The mention to inadequacy of some pedagogical methods is a curious discourse also found thirty years later in several documents about the Bologna Process.

Finally, the third problem is the apparent insufficiency of the whole system to respond to changes in the social and professional 
requirements (Nunes, 1968). The existence of a technological and organizational gap between the most and the less industrial and economic developed countries could be seen as an incitement to the building of a united Europe and to the modernization of activities (Sousa, 1968). Democratization of the access to University could be seen as a route to broad the qualified human resources Portugal needed to face economic, technological and social challenges (Sousa, 1968). Technological changes in production systems and changes in the work and employment structures suggest for policies to remove obstacles in the access to graduate education and to lifelong education (Nunes, 1966; Rocha, 1968; Sousa, 1968). The expectation about the rising number and diversity of candidates generated a great concern on the system capacity to accommodate that expansion. From that, the concern is the risk that a desirable and essential process to the Portuguese society, the democratization of access, turn on a paradoxical effect of jamming in the access and overcrowding of institutions because of the structural, functional and pedagogical incapacity of institution to deliver education for all the candidates and with an acceptable level of quality (Guerra \& Nunes, 1969). As Nunes say (1966, p. 686) «if the university have to transform is because around it the own society is transforming and want to transform".

Later, in 1971, the World Bank produced a Sector Working Paper that identifies several trends in educational development including topics related to quantitative expansion, efficiency and productivity of education systems, and the contribution of education for the labor market (WB, 1971). An OECD meeting in 1973 made clear that a simple increase in dimension of the institutions or their replication, 'more of the same' strategies, would not be the best solution to cope with all the problems of higher education, as the increasing numbers, a more diversified 
student body and the rapidly changing manpower needs of highly industrialized societies (OECD, 1974). A problem identified in early 70's was a discrepancy between the supply of and demand for skills adjusted to the labor market, generated by a response given by the education systems to increasing demand based on those solutions (OECD, 1974; WB, 1974). As so, OECD considered that Universities should undergo major changes. An envisaged strategy was a diversification of post-secondary systems, through the development of a variety of extra or nonuniversity institutions and programs originally created to provide terminal and, for the most part, vocationally oriented postsecondary education (OECD, 1974). From the assessment about the expansion of world education systems and the suggestions produced, these documents became important to support the idea of change in Portugal.

Caetano (1974) declares that when he was appointed for Prime Minister, in 1968, he assumed the urgent need to make a broad reform of the education system. About higher education two problems seemed especially relevant for the Government: the pressure to expand the system, broadening the access and increasing the institutional capacity to accommodate students; and the political mobilization and pre-revolutionary environment in academic institutions. From 1968 onwards the new Prime Minister Marcelo Caetano, gave opportunity for regime openness to some development challenges, namely a reform of higher education under supervision of Veiga Simão, the Ministry of Education. In 1973, the Government produce two legal diplomas that translate the reformist idea. Law n. 5/73, 25/07/1973, established the basis for the organization of the whole education system. The DecreeLaw n. 402/73, 11/08/1973, created new Universities, but the most innovative issue was the creation of Polytechnic Institutes and other non-University institutions. This is the fundamental 
legal diploma to convert the institutions and programs of 'Ensino Médio' into the new short-cycle institutions and short-cycle higher education institutions as recommended by OECD. After the 1974' Revolution but still under that juridical scheme, several institutions of 'Ensino Médio' change their statutes and became included in higher education system.

The 1973' reform became an important opportunity for systemic diversification generating a binary system. In fact, an additional merit of that reform is that the idea survived the change of the regime and the whole revolutionary aftermath, and it has never been repealed. More than that, even with adjustments it became the basis for the change of the national higher education system.

In the 1973' reform and even during the Provisional Governments (1974-1976, until the approval of the new Constitution) the Government Programs and legislation refers to 'University', with a university component and a non-university component. On the first two Constitutional Governments (19761978) the idea of system deepens and emerges the designation of 'Higher Education'. At the same time there seems to be a concern to create an identity to the non-university sector, and it became to be called as 'Short-Term Higher Education'. The V.th Constitutional Government [CG] Programme introduces the term of 'Polytechnic Higher Education'. A legal diploma (DecreeLaw n. 513-L1/79, 27/12/1979) from that Government determines definitely the binary character of the system, lately confirmed through the approval of the specific academic career (DecreeLaw n.185/81, 01/07/1981 - VII.th CG).

The concession of the final designation (V.th CG), the creation of the academic career (VII.th CG), the concession of autonomy (XI.th CG), and changes in the educational structure in the context of Bologna Process (XVII.th CG) became fundamental 
for the consolidation of the Polytechnic Higher Education subsystem. However, although the equal formal statute clearly established in the Juridical Regime for Higher Education (Law n. 62/2007, 10/09/2007) still include some differences, being the most symbolic the fact that Polytechnics cannot grant the third cycle degree.

The participation of Portugal in the Declaration of Bologna (1999) and full adoption of the Bologna Process turn to be the opportunity to make a reform in the national higher education system and to modernize it, in the sense of making it more suitable to academic mobility and evaluation in the international arena. The reform imposed the need to update the juridical framework for higher education. The binary option became confirmed on the revision of the legal and normative framework for higher education made in the first decade of XXI.th century.

\section{A new agenda for higher education in Europe}

There is a difference between the Bologna Declaration (1999) and documents that precede it such as the Magna Charta Universitatum (1988) and the Sorbonne Declaration (1998), on one hand, and the monitoring reports about the implementation of the Bologna Process, on the other hand.

Especially in documents previous to Bologna Declaration there is an emphasis in arguments of internal benefits for the system of higher education, even if there is a transfer from particular national interest to a set of common interests for the whole European system. On those documents the discourse in centered in issues of the system and the autonomy of institutions seeking for the progress of knowledge, with some mentions to the contribution of the higher education for 
society. Sorbonne Declaration (1998) states clearly that facing some steps in European process of political development "they should not make one forget that Europe is not only that of the Euro, of the banks and the economy: it must be a Europe of knowledge as well». And for that "we must strengthen and build upon the intellectual, cultural, social and technical dimensions of our continent" (Sorbonne Declaration, 1998). This doesn't mean blindness for economic issues. In fact even in 1988 the Magna Charta Universitatum stated that «universities' task of spreading knowledge among the younger generations implies that, in today's world, they must also serve society as a whole; and that the cultural, social and economic future of society requires, in particular, a considerable investment in continuing education".

Bologna Declaration marks a pivotal point in the quest for a change because it spells out clearly a set of objectives intended to raise international competitiveness of the European higher education as a whole. This Declaration recognizes the 'Europe of Knowledge' as an "irreplaceable factor for social and human growth and as an indispensable component to consolidate and enrich the European citizenship". The idea comprises the capacity of "giving its citizens the necessary competences to face the challenges of the new millennium, together with an awareness of shared values and belonging to a common social and cultural space» (Bologna Declaration, 1999). This change seems to have got some momentum from the conclusions of the European Council meeting held on 23-24 March 2000 in Lisbon. The document presents a «quantum shift resulting from globalization and the challenges of a new knowledge-driven economy" affecting every aspect of people's lives and requiring a radical transformation of the European economy. Also the need to «set a clear strategic goal and agree a challenging Programme 
for building knowledge infrastructures, enhancing innovation and economic reform, and modernizing social welfare and education systems" (European Council, 2000, p.1). From that, it raises a "new strategic goal for the next decade: to become the most competitive and dynamic knowledge-based economy in the world, capable of sustainable economic growth with more and better jobs and greater social cohesion" (Lisbon European Council, 2000, p.2). To European Union, Europe only would achieve that major goal if education and training work as growth factors for the economy, research, innovation, competitiveness, sustainable employment and social inclusion, and active citizenship. Later, in the monitoring reports of the implementation of the Bologna Process, pointing to the creation of the European Higher Education Area, there are several ideas that are gradually imposing their presence and direction to the Bologna Process. Considering the contribution to economic and social development and social cohesion we find ideas as: lifelong learning, employability, modernization and a new structure for higher education systems; emphasis on quality assurance, adequacy to diverse social and economic environments and accountability; innovation as a competitiveness factor for institutions and for economy at large.

The change in discourse strongly suggests a mutual influence to leverage changes envisaged by both interest areas: the higher education (Bologna Declaration, 1999) and the economy (Lisbon European Council, 2000). It is the coalition of an academically seductive discourse about modernization and quality assurance with the agenda for competitiveness and economic growth from the Lisbon Strategy. The connection between the reform of the higher education systems in Europe, in the context of the Bologna Process, and the economic arguments whatever its interests, can be seen in some concepts we can identify in 
several documents. The economic arguments may have a direct interest to the system of higher education, as the efficiency of the system, or they may have an external interest, in the sense of relevance of transferable knowledge for companies or community.

\section{Higher education and economic rhetoric}

Jean Monnet and Robert Shuman had the federalist idea and belief on an integrated Europe where international organizations would embody a moral authority higher than that of NationStates, as a path to heal the World War II wounds and to prevent or overcome deep and irremediable contradictions between States. Instead, the project of European integration assumed a pragmatic and functionalist character and "tended to focus on the means of promoting economic cooperation, seen by states as the least controversial but most necessary form of integration" (Heywood, 2007, p. 152).

In 1955, during negotiations to build the European Economic Community (EEC), there was a proposal for a European University as a contribution to build a community of knowledge and to share a European cultural dimension. It was considered as a way to override differences to USA and, through research, contribute to innovation and the cultural, social and economic dimensions of that community (Corbett, 2005). The perspective of a relation between higher education and economy becomes quite interesting when analyzing the relation between Europeanist rhetoric about higher education and the development of structures and projects on economic development for countries gathered in a European community. There is a linkage between a process of economic character 
as the Lisbon Strategy (Lisbon European Council, 2000) and a process of organizational and educational character seen in the Bologna Process.

As Meyer and Rowan (1977, p. 343) say "in modern societies, the elements of rationalized formal structure are deeply ingrained in, and reflect, widespread understandings of social reality". It means that some elements of formal structure of organizations became expressions of powerful institutional rules which function as highly rationalized myths that are binding on such organizations. Those rules are enforced by public opinion, by the views of important constituents, by knowledge legitimated through the educational system, by social prestige or by the laws (Meyer, \& Rowan, 1977). The idea of globalization used in politics, economy, culture and even in everyday life to give sense to several social transformations and to undertake some action in accordance with that, bring together some other myths associated with it: a minimalist State, a feature that emphasizes a reduction of the central regulative and intervening role of State in favor of a mediating role; the value of entrepreneurialism and managerialism as management paradigms; and the idea of knowledge society, linked to technological development, to its effect over social relations, and to the rhetoric of competitive advantage (Vaira, 2004).

Myths have consequences over organizational arrangements and social legitimacy of higher education institutions. Supranational agencies and actions, such as the Bologna Process, set political orientations about higher education that define models of institutional arrangement and operation. These models operate as archetypes or templates that States are impelled to embed in their national contexts for political legitimization and as a positive signal of social development. A 
general and common framework on structure and performance are set in motion based on ideas of effectiveness, efficiency and success, contributing to legitimize, objectify and reproduce those institutional myths. That model may arise in the form of a kind of 'reform packages', very similar in contents, means, orientations and goals, and a common rhetoric shared by different political parties breaking through ideological boundaries (Vaira, 2004).

In the last few decades, terms as 'internationalization' and 'globalization' have increased their importance in rhetoric about higher education. The concept of internationalization has an underlying meaning of increase in cross-border activities between national higher education systems that still retains their own autonomy and decision power while the concept of globalization suggests blurred national limits relating the activity of national systems (Guri-Rosenblit, Sebková, \& Teichler, 2007; Teichler, 2004; Zha, 2009). As so, the creation of a European Higher Education Area seems a kind of regional version at world dimension of the globalisation process (Teichler, 2004). On the other hand, Teichler (2008) also points that the term 'globalization' "is used to underscore that higher education is increasingly affected by worldwide economic developments which weaken national regulation, put a stronger emphasis on market mechanisms" (p. 364), and the use of that concept shows a stronger emphasis on market mechanisms challenging the institutional units to strengthen their position in the reputational hierarchy to compete globally (Teichler, 2004, 2008). At the same time, the use of this concept suggests relatively steep vertical diversification of the institutional pattern of higher education is acceptable or even desirable without advocating certain formal dimensions of vertical diversity (Teichler, 2004, 2008) 
that may be politically sensitive in national context. So, the argument for vertical diversity is diverted to the idea to reinforce country prestige through the position of national institutions in a worldwide competition. As Teichler (2008) points, "at the apex of the system, the institutions do not play anymore in national leagues, but rather (...) in a champions' league" (p. 366).

By the ending of XX.th century the Bologna Declaration and some previous documents translate the hope to create a kind of architectural blueprint to higher education, a contribution to create a new idea of Europe in social, cultural, intellectual and technical dimensions. The European Union has appropriated and turned it an instrument, seeking to strengthen the economy as a way to reach social objectives. Amaral (2002) highlights a significant change in discourse about higher education: from the 'harmonization' in the first documents (as the Sorbonne Declaration, 1998), to 'convergence' and later to 'tuning' in documents of the Bologna Process. Even the Bologna Declaration (1999) does not use 'harmonization' but instead there are several mentions to 'cooperation' in actions (educational cooperation, cooperation in quality assurance) and levels (inter-institutional cooperation and inter-governmental cooperation). But these are not the only changes in discourse. Along the Reports from the meetings of European Union Ministers responsible for higher education, attaining goals and priorities to accomplish the European Higher Education Area, terms as 'qualification' and 'employability' got more importance as they carry a sense of preparedness, of applicability and relevancy of knowledge, instead the traditional terms of education and employment (Table 1). Especially in a market driven or even more liberal discourse, employment is no longer a granted right. 
Table 1. Some concepts present in European documents

\begin{tabular}{|c|c|c|c|c|c|c|c|}
\hline \multicolumn{2}{|c|}{ Document } & Year & 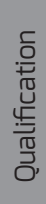 & 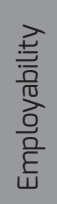 & 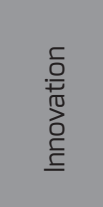 & 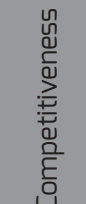 & 菢 \\
\hline \multicolumn{2}{|c|}{ Sorbonne Declaration } & 1998 & $x$ & $x$ & & & $\times 5$ \\
\hline \multicolumn{2}{|c|}{ Bologna Declaration } & 1999 & $x$ & $x$ & & $\times 5$ & $\times 5$ \\
\hline EU & Lisbon Strategy & 2000 & $x$ & $x$ & $\mathrm{XR} / \mathrm{XE}$ & $X E$ & $X R$ \\
\hline \multirow{8}{*}{ 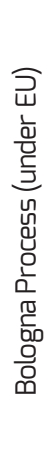 } & Prague Communiqué & 2001 & $x$ & $x$ & & XS/XE & $\times 5$ \\
\hline & Berlin Communiqué & 2003 & $x$ & $x$ & XE & $\times 5$ & $\times 5$ \\
\hline & Bergen Communiqué & 2005 & $x$ & $x$ & XS / XR & $\times 5$ & $\times 5$ \\
\hline & London Communiqué & 2007 & $x$ & $x$ & XS /XR & $\times 5$ & $\times 5$ \\
\hline & Leuven Communiqué & 2009 & $x$ & $x$ & $\begin{array}{l}\text { XR/ } \\
\text { XRE }\end{array}$ & $\times 5$ & $\times 5$ \\
\hline & Budapest-Vienna Declaration & 2010 & $x$ & $x$ & XE & $x$ & XS \\
\hline & Bucharest Communiqué & 2012 & $x$ & $x$ & $X S / X E$ & & $\times 5$ \\
\hline & Yerevan Communiqué & 2015 & $x$ & $x$ & $x$ & & \\
\hline
\end{tabular}

Notes: $\mathrm{S}$ - for the higher education system; $\mathrm{R}$ - for research; $\mathrm{E}$ - for economy.

The 'Communication from the Commission - The role of the universities in the Europe of knowledge' (CEC, 2003) points three economic challenges to higher education institutions and systems. First, to consolidate excellence in research and teaching and to increase the international attractiveness of European higher education institutions and, as so, to achieve enough and sustainable resources and use them efficiently. Second, their contribution to an useful knowledge and qualification allowing a better response to local and regional needs and strategies, and the emergence of an open European labor market without the 
problems concerning the recognition of qualifications country by country. Third, to establish closer cooperation between universities and enterprises geared more effectively towards innovation, the startup of new companies and, more generally, to ensure the transfer and exploitation of new knowledge in the economy and society at large.

\section{Changes in the rhetoric of Portuguese government Programs}

After the revolutionary phase (1974-1976) and implementation of the new political regime brought by the 1974' Revolution, two political parties emerged as the main representatives of the majority of voters and key players in the process of democratization in Portugal: the Socialist Party (PS) and the Social-Democrat Party (PSD) (Lobo, 2000). Solely or as distinct coalition leaders, these parties have been responsible for most of the Governments since 1976. So, although the electoral plurality, there is a kind of bipartisanism in Constitutional Governments (Jalali, 2003).

Merkel and Petring (2007) consider the existence of three general types of social-democrat parties: traditional parties emphasize redistributive regime, with a highly regulated labour market; the modernized social-democratic parties do not liberalize existing structures of the welfare state and the labour market, and do not replace the welfare state but do some adjustments to cope with a changing context of global competitiveness; finally, the liberal social-democratic parties do partially replace state regulations with market solutions converging towards liberal ideas of a provision of social-political minimum standards and the inclusion into the markets due to economic pressure (Merkel \& 
Petring, 2007). From the classification of welfare regimes made by Esping-Andersen (1996), Pennings (1999) presents three welfare state responses to economic and social change: the continental route, clearly more conservative; the Scandinavian or Nordic route of social investment; and the Anglo-Saxon route of neoliberal inspiration. These welfare regimes keep some proximity to the previous contexts of social-democracy.

It is important to not confound the name of the parties and their political advocacy. Parties can do slight ideological adjustments, they can change their discourse and the effect of their political initiatives may produce different results for different countries, and even for different circumstances of politics in the same country. The 'Scandinavian' social-democracy in the last decades of XX.th century in Nordic countries is more approximated to the political space that in Portugal have been occupied by the socialist party since late 90's. In fact, Portuguese socialist party, considering its Government Programs, has changed its position from the left-wing to central-left, while the Portuguese social-democrat party has moved to the rightwing. Meanwhile, these two parties have been acting as a big political block moving together and dominating the spectrum from centre-left to centre-right. This condition represents the domination of political discourse by mainstream parties, older democratic parties (Busemeyer, Franzmann, \& Garritzmann, 2013) and a steady increase in consensus around a desirable issue for society and for political propaganda especially for electoral campaigns (Jakobi, 2011). In fact, the logic behind party action is not just sociologic representing a population sector but also political in the sense of dealing with electoral power to attain social and economic objectives (Busemeyer, 2009). So the result was a trend to narrow the gap between mainstream traditional parties and a general move of those political families to the 
right in the political spectrum, including socialists in the place previously occupied by social-democrats (Knutsen, 1998).

The political-parties discourse tends to assign to the higher education a status as essential sector for the efforts of national development, from the education in specialized areas of knowledge to the culture. The higher education system is considered relevant to solve problems and to meet several issues of national interest, of social, economic or technological character (Clark, 1983). Nowadays higher education, through learning, research and knowledge transfer to industry and other production sectors, is accepted as an important source of innovation and economic development and an instrument to promote social cohesion (Triventi, 2014). Education is considered able to compensate for differences and educational gaps arising in early childhood, and equal access to education therefore helps to secure equality of opportunities (Sauer \& Zagler, 2014).

Ansell (2008) considers that higher education policy, as he studied in OECD countries, is driven by a set of partisan choices within what he calls a 'trilemma' between the level of enrollment, the degree of subsidization, and the overall public cost of higher education (Ansell, 2008).

In an elite system left-wing parties have limited gains from public funding for higher education, since their electorate do not profit from it (Jungblut, 2014). So, while right-wing parties favor greater public spending on higher education and expansion of enrollment, protecting the interest of its traditional electorate, left-wing parties are more reluctant to expand public funding and enrollment until enrollment has already reached mass levels. Accordingly, initial moves towards the mass public model are made by right-wing governments (Ansell, 2008). In Portugal this process was initiated by a conservative Government prior to the 1974' Revolution. Once a mass enrollment system has been 
attained, those partisan preferences switch, with left-wing parties more sensitive to the expansion and quality of higher education through increased public funding and right-wing parties seeking to limit further expansion (Ansell, 2008). Later, there seems to be a convergence of large centre parties, being the strongest proponents of educational expansion while parties on the more extreme ends of the political spectrum are less supportive of expanding education (Jungblut, 2014).

In fact, it seems that current partisan composition of the Government may not be the sole explanatory factor, but several other factors such as the level of economic development, the institutional and systemic structure and the whole level of public social spending are determinants of public education spending in OECD democracies (Busemeyer, 2007). These features show how the political position of parties about higher education might be conditioned by the structure of the existing higher education system (Ansell, 2008). Ansell (2008) also notes that Bologna Process may generate unlikely political alliances across left-right boundaries.

Until 1999 there is a rotation between two visions about the relation of social and economic issues but always with the assumption that higher education has an important role to accomplish policies. One vision emphasizes the economic component, which means that vision relies on the rationale that education and training are essential to create employment, work is essential to produce, and the enrichment allows for better living conditions (PSD' Government Programs). Other vision emphasizes the social component instead. The rationale is based on the idea of public investment to generate employment and new opportunities of inclusion (PS' Government Programs). From primacy of economy to generate a social profit there is a change to the primacy of solidarity to assure economic capacity. 
Several Government Programs of PSD also adopted the discourse of reducing the weight of State in economy, increase efficiency of public institutions, adoption of organizational models based on flexibility, autonomy and responsibility, and competitiveness of production and economic structures. Qualification of human resources is seen mostly as a production factor.

Until the 70's prevail an idea of the university as foundational for the democratic society, capable to provide citizens with the resources to take advantage of the best social opportunities emerging from the economic development and a place of intellectual independence and resistance to a corporative society (Zomer \& Benneworth, 2011). The analysis of Portuguese Government Programs since the 1974' Revolution until 1999, when Bologna Declaration was signed, reveals an evolution in the societal functions of higher education. In particular, there is a change from a utilitarian function to the ideological and cultural reform of society, to new ideas about the State organization and the social and economic transformation reinforced by the desire to modernize the society and economy, introduce technological innovation and to bring Portuguese economy closer to the other countries of the European Union.

In the beginning of 80's, economic crisis seemed to have an effect of reducing the willingness of State to keep the full independence of academy. That is, by a steady adoption by State of market mechanisms and a promotion of international relations, university become more and more in comparison with other institutions from other countries and competing for transnational resources. This condition forces a strategic appreciation of their 'third mission', the relation with community and industry because of its social and economic relevance (Zomer \& Benneworth, 2011). This is precisely what happens in Portugal during that period under social-democratic parties in the Government. As a result of that 
there are changes in Government Programs about the relevance of higher education for the national economy and a stronger emphasis in professional training and vocational higher education. It is also interesting to note that in the whole evolution of the binary system in Portugal, the economic relevance was a strong issue for the development of polytechnic higher education subsystem. This issue adopts the form of three arguments: the education and training for technical jobs and careers (qualification argument); the willingness to engage in applied research and transferable knowledge (the innovation argument); and as instrument for regionalization of higher education through a closer response to local and regional needs from the predominant industry (the expansion/regionalization argument).

In late 90's there is a political drift of the discourse of Socialist Party in the Government (XIII.th CG, 1995-1999; followed by XIV.th CG, 1999-2002) to the centre. In fact more and more the mainstream parties adopt a pragmatic and utilitarian perspective. There is still a difference in the ideological basis and political priorities, but pragmatic measures bring PS and PSD closer each other. Ideas about the structure of State and economic planning seen in previous PS' Government Programs to induce social and economic transformation are changed after full integration in European Community. The pragmatic position of socialists means that matter is no longer an egalitarian solidarity from a Marxist inspiration but instead is a solidarity based on the opportunity of economic benefit. It is a change from a revolutionary socialism to a democratic socialism, more pragmatic, reformist and closer to social-democracy, accepting capitalist instruments like markets. At the same time, socialists start to step back from economy by doing some steady transfer of responsibility and acceptance of a model of management based on accountability and evaluation, and a regulatory State. 
With the beginning of XXI.st century we can identify three major periods in the discourse of Government Programmes. First period comprises a Government (XIV.th CG, 1999-2002) lead by PS and a brief PSD' Government (XV.th CG, 2002-2004). It is the time to fully apprehend the new paradigm of higher education objectively generated by the Bologna Declaration (1999). The PSD Government represents already a turn to the vision of strengthening the economy to generate resources and then accomplish social objectives. The challenges of quality assurance, competitiveness and technological innovation are assumed as strong arguments to reinforce continuous professional training, post-secondary training and vocational higher education, and also a close link to industry.

A second step started in 2004 with the XVI.th Government supported by PSD and was followed by two socialist Governments (XVI.th CG, 2005-2009; XVII.th CG, 2009-2011). It is the period of implementation of the Bologna Process. Initiated slightly in 2003 by some involvement of social and professional partners, the full completion would come with the directives from the meetings of European Union Ministers responsible for higher education, attaining goals and priorities to accomplish the European Higher Education Area. That is precisely the moment of the most intense change in the political discourse of socialists. There is wider acceptance of arrangements and interests of an Europeanized/globalized market and it is adopted a new strategic vision for Portugal trying to conciliate the idea of Welfare-State, traditionally linked to socialist' discourse, to acceptance of markets as instruments of economic policy, as accepted by social-democrats, and benefits from ideas of modernization, qualification, innovation and competitiveness. It is also a discourse of political opportunity at European level as a means to share from the social and economic models and be 
side-by-side with other countries of European Union and also a relevant position in international context. Especially since 2005 (XVII.th CG) there is a broad revision of the legal structure for higher education. Beyond that, in 2007 is created a national Agency for Evaluation and Accreditation of Higher Education (Decree-Law n.369/2007, 05/11/2007) directed to reinforce the implementation of the revised legal and normative framework for higher education. It sets a new challenge to all institutions.

From 2011 onwards there is a third period, starting with PSD' Governments (XIX.th CG and the very brief XX.th CG) followed by a socialist Government (XXI.st CG) since 2015, supported by a parliamentary arrangement with left-wing parties. The period started under a deep economic crisis that affected financial support and sustainability of the system. This is a period of a stabilization in the number of institutions. The PSD' Governments emphasize continuous training to provide transverse and multifunctional skills to promote entrepreneurship, independent and innovative jobs.

\section{Bologna Process and ideas of higher education and economy}

The terms we have identified from the European documents were not yet central in the discourse of Provisional Governments in Portugal (1974-1976). These Governments were constrained in time and range of political and social intervention by the necessity to make changes in Constitution, and to establish new philosophical and legal basis for governance. They were also constrained by ideology because they were grounded in a document of the revolutionary Movement, advocating a socialist reform of the State. So, the Government Programs are 
quite limited in range and policies they advocate. In fact, they emphasise general principles and social and economic actions intended to improve the quality of life and the building of a 'more equal and fair society'. State is the major agent to implement the 'transition to socialism' but there is still a space to include private and cooperative sectors in economy. Education as a whole and higher education in particular are considered to have a fundamental role in the reform of the society. Before the Revolution, University was considered a political indoctrination and opposition centre against the regime. Now it became an instrumental agent to develop the democratic culture of the new generations of students and the country.

From 1976 onwards, with the Constitutional Governments, there is in fact an adjustment in Government Programs rhetoric. Although the IX.th Government (coalition government of socialists and social-democrats, even so, for no longer than two years, 1983-1985) education/training and employment are the terms usually found. A concept linked to economy is productivity, since there is a recurrent concern about the economical crisis in the country, partially due to a legacy of structural problems coming from before the Revolution and also to some disruption of the industrial fabric after the Revolution. At almost every Government Program we can find explicitly that concern. The block made by X.th- XII.th Governments (1985-1995) organized by social-democrats deepens the linkage between education/ training and economy. Terms as 'qualification', 'innovation' in research and its interest to industry and technological sectors, to enhance 'competitiveness' and economic 'productivity' become important issues in those Programs, namely in the discourse about higher education. These three Programs make clear a difference of social-democrats (PSD) to socialist' Programs: on PSD Programs the discourse about State organizations is much 
directed to the reduction in State intervention in economy, while reinforcing the private sector participation. Professional training and vocational higher education are quite valuated as a mean to support qualification and to reconvert and upgrade professional skills. A full utilitarian value of education and training emerges to enhance what later will be termed 'employability' and economic development.

The XIII.th Government (1995-1999) and the XIV.th Government (1999-2002) of Socialist Party (PS) mark the new time of Bologna Declaration. From now on, every Government Program includes the ideas of 'qualification', 'employability', innovation' in the sense of innovative, transferable technological innovation and in the sense of new forms of administrative organization of State and organizations intended to reduce costs and increase efficiency. Other important terms recurrently found are 'productivity' and 'competitiveness', concepts applied both to economy and to the research and higher education system.

\section{Concluding remarks}

The evolution of the higher education system in Portugal, since 1973, can be characterized by a cluster of issues in interaction: access, expansion, diversification and regionalisation or territorial dispersion. The overall expansion in access, expansion in number of institutions, and diversification of the higher education system in Portugal is a reality and continuous process along the last forty years, but it is not a homogenous process. There are differences in the rhythm in time and between regions with periods of growth, stabilization or even some reduction. In the whole process the economic relevance of higher education has been an important argument. As mentioned before, Portuguese research in the 
sixties have shown how much the societal change has introduced not only cultural but also economic arguments as drivers for change in the University.

The system is formally binary but it is not exactly equal. It means that there is some imbalance as a birth mark of the Polytechnic subsystem. It has not been born from the traditional and prestigious University by a process of differentiation generated from the will of autonomy of some academic disciplinary sector trying to state its difference. On the contrary, it is a top-down process confronting the university monopoly of a higher education statute. Institutions and programs were promoted to higher education by law. It had major consequences. During some decades, occurred a process of academic drift, an isomorphic process (DiMaggio \& Powell, 1991) to emulate some characteristics of the University, the academic reference. The Bologna Process brought the opportunity of a challenge to Polytechnics to consolidate its own identity and prestige. We have to make clear that the issues here are solely differences at social-academic statute, not the quality of management, teaching, research or knowledge transfer.

The major organizational reform of higher education in Europe launched in the nineties of XX.th century became an opportunity to merge interests of the system, the society and the State. It was the opportunity to generate a wide higher education area, a 'Europe of Knowledge' as a condition to promote human and social growth, to consolidate the European citizenship and to develop and strengthen stable, peaceful and democratic societies. This reform was intended around a new organizational structure, academic mobility and exchange of knowledge but there is a consciousness about the need of an objective and a bridge between the academy and the society with mutual benefits for mutual sustainability. The Bologna Process by European Union 
is the result of a convergence of the Bologna Declaration (1999) and the Lisbon Strategy (2000).

Portugal has completely adopted the advocated higher education reform. Whatever it be considered a harmonization process or a full convergence process, it can be seen as an allomorphic process because to a common level of strategic decision and political declaration match several forms to operationalise it (Machado, Ferreira, Santiago, \& Taylor, 2008; Faber \& Westerheijden, 2011). As a concept it means that a model for a broad landscape may and is effectively adjusted to national or local contexts according to political, social or cultural features (Vaira, 2004). Although the pressure to share a model, institutions may not become more homogenous. They retain capability to do at least some strategic choices and their own organizational culture but, at the same time, without a cultural retrenchment or refusal of influences from society (Zha, 2009). Faber e Westerheijden (2011) point the idea of operationalization levels which mean that there might be an upper political level of acceptance for major organizational features and a lower level at institutions that hold the ability to maintain diversity in the system. As so, Bologna process may be considered a soft policy because prescriptions are followed in a voluntary basis. The 'framing effect' persuades domestic policy-makers to reflect on external prescriptions and then construct their proposals within the limits of these frameworks. The result is compatibility at high level of political organization between States, while prescriptions are fitted to national interests (Faber \& Westerheijden, 2011; López-Santana, 2006).

At the political level clear changes have been made in the rhetoric of Portuguese Governments' Programs. These documents go far beyond parties electoral manifestos because Programs are the basis for the assessment and political judgement over the 
performance of Governments. The macro-structural adjustment has been made and the binary system reaffirmed. All of this happened at the same time that mainstream parties adjusted their discourse. Government Programs lead by Social-Democratic Party always had a more market-friendly discourse but along the first decade of XXI.th century it came closer to a neoliberal position. Socialist Party has traditionally emphasized the social primacy over the economy but the rhetoric in Government Programs reveals a steady closeness to the centre. It is 'the owner' of the central-left of the political spectrum.

The merge of the goals of Bologna Declaration and Lisbon Strategy provided Governments with an opportunity to ideological change and to infuse a structural reform of the public administration alleging modernization and efficiency arguments.

At higher education system level, facing a European political wave of acceptance of a common market for employment and funding resources for higher education and applied research Portuguese Governments grabbed the opportunity. For the system to be attractive, high quality teaching and research is essential and graduates competence must be fully recognized in employment market. At the same time Portuguese Governments avoided political costs of non-adhesion to the Bologna Process. This way Portuguese Governments revealed a real pragmatism in their choices about higher education.

At institutional level, the Bologna Process and the quality assurance and accreditation system implemented create an opportunity to social legitimization and prestige, to attract new candidates and to stimulate research and the quest for funding.

Even before the Bologna Process, Amaral e Teixeira (2000) pointed how the expansion and diversification of the higher education system in Portugal had been impaired by some uncontrolled proliferation of private sector, by the academic drift 
of Polytechnics that delayed the building of the subsystem identity and the State that had not fully undertake its responsibility and competence for monitoring and regulate the system. Several studies have been made showing the insufficient contribution of sectors to diversification (Almeida \& Vieira, 2012; Amaral \& Teixeira, 2000; Amaral et al., 2000; Correia, Amaral, \& Magalhães, 2002; Teixeira, Rocha, Biscaia, \& Cardoso, 2012). A consequence of that seemed to be stratification in the system (Amaral \& Teixeira, 2000; Fonseca, Encarnação, \& Justino, 2014).

Kogan (1997) presents the stratification process in higher education as a consequence of the massification in terms of the diversity of students and interests, and increased pressure from the employment market. Gumport (2005) underlines how development of economy based on knowledge and the economic value of research and technology generates a competition for resources needed to sustain the knowledge production.

Competitive conditions between institutions, their differences in strategic options and scientific potential contributes inevitably to differences in quality. Even in a legal frame of formal equality the absence or malfunction of a regulatory element in the system contribute to deep the vertical difference in quality of the institutions. But we think that in conditions of unavoidable competition between institutions, if institutions, the regulatory element, and the State adopt a 'race to the top' position, the system and each sector may not loose entirely from stratification. It does not mean stratification is desirable or not. The pragmatist view is the challenge to adopt procedures directed to improve quality and sustainability of each institution, reducing the effective differences in quality (even if they are equal in legal statute), and raising the quality of the system as a whole. Acceptance and implementation of the Bologna Process in a country cannot be seen as a straight condition to make the 
system more competitive and attractive for students and to guarantee more employability to its graduates. In Portugal, the existence of a real evaluation and accreditation system and agency for higher education is an opportunity for institutional investment in quality and to deepen the identity of sectors in the binary system.

\section{References}

Almeida, A. N., \& Vieira, M. M. (2012). From university to diversity: the making of Portuguese higher education. In G. Neave, A. Amaral (Eds.) Higher education in Portugal 1974-2009 - A nation, a generation (pp. 137-159). Dordrecht: Springer. ISBN 978-94-007-2134-0

Amaral, A. (2002). O Processo de Bolonha. Da harmonização à sintonização, passando pela convergência. Porto: CIPES e Universidade do Porto.

Amaral, A., \& Teixeira, P. (2000). The rise and fall of the private sector in Portuguese higher education. Higher Education Policy, 13(3), 245-266.

Amaral, A., Correia, F., Magalhães, A., Rosa, M. J., Santiago, R., \& Teixeira, P. (2000). O ensino superior pela mão da economia. Matosinhos: CIPES Fundação das Universidades Portuguesas.

Ansell, B.W. (2008). University challenges: Explaining institutional change in higher education. World politics, 60(2), 189-230.

Bergen Communiqué (2005). Bologna Follow-Up Group. Available at: http:// www.ehea.info/pid34363/ministerial-declarations-and-communiques.html

Berlin Communiqué (2003). Bologna Follow-Up Group. Available at: http:// www.ehea.info/pid34363/ministerial-declarations-and-communiques.html

Bologna Declaration (1999). Joint declaration of the European Ministers of Education. Available at: http://www.ehea.info/pid34363/ministerial-declarations-and-communiques.html

Bucharest Communiqué (2012). Bologna Follow-Up Group. Available at: http:// www.ehea.info/pid34363/ministerial-declarations-and-communiques.html 
Budapest-Vienna Declaration (2010). Bologna Follow-Up Group. Available at: http://www.ehea.info/pid34363/ministerial-declarations-and-communiques.html

Busemeyer, M. R. (2007) Determinants of public education spending in 21 OECD democracies, 1980-2001. Journal of European Public Policy, 14(4),582-610.

Busemeyer, M. R. (2009). Social democrats and the new partisan politics of public investment in education. Journal of European Public Policy, 16(1), 107-126.

Busemeyer, M. R., Franzmann, S. T., \& Garritzmann, J. L. (2013). Who owns education? Cleavage structures in the partisan competition over educational expansion. West European Politics, 36(3), 521-546.

Caetano, M. (1974). Depoimento. Rio de Janeiro: Record.

Carvalho, R. (2008). História do Ensino em Portugal. Lisboa: Fundação Calouste Gulbenkian. ISBN 978-972-31-0173-7

CEC - Commission of the European Communities (2003). Communication from the Commission - The role of the universities in the Europe of knowledge. $\operatorname{COM}(2003) 58$ final (05.02.2003). Brussels: European Commission.

Clark, B.R. (1983). The higher education system - Academic organization in cross-national perspective. Berkeley: University of California Press. ISBN $0-520-04841-5$.

Corbett, A. (2005). Universities and the Europe of knowledge: ideas, institutions, and policy entrepeneurship in European Union higher education policy, 1955-2005. Basingstoke: Palgrave MacMillan. ISBN-13 978-1-4039-3245-7 ISBN-10 1-4039-3245-X

Correia, F., Amaral, A., \& Magalhães, A. (2002). Diversificação e diversidade dos sistemas de ensino superior: o caso português. Lisboa: CNE. ISBN 972-8360-16-9

Cruzeiro, M. E. (1970). A população universitária portuguesa: uma nota estatística. Análise Social, VIII(32), 721-740.

DiMaggio, P. J. \& Powell W. W. (1991). The iron cage revisited: institutional isomorphism and collective rationality in organizational fields. In W. W. Powell, \& P. J. DiMaggio (Eds.), The new institutionalism in organizational analysis (pp. 63-82). Chicago: The University of Chicago Press. 
Esping-Andersen, G. (1996). After the Golden Age? Welfare state dilemmas in a global economy. In G. Esping-Andersen (Ed.), Welfare states in transition: national adaptations in global economies (pp.1-31). London: Sage. ISBN 9780761950486

European Council (2000). Lisbon European Council 23 and 24 march 2000 - Presidency conclusions. Available at: http://www.europarl.europa.eu/ summits/lis1_en.htm

Faber, M. \& Westerheijden, D. (2011). European degree structure and national reform - Constitutive Dynamics of the Bologna Process. In J. Enders, H. F. De Boer, \& D. F. Westerheijden (Eds.). Reform of higher education in Europe (pp. 11-28). Rotterdam: Sense. ISBN 978-94-6091-553-6

Fernandes, T. (2014). Rethinking pathways to democracy: civil society in Portugal and Spain, 1960s-2000s. Democratization, 1-31.

Fonseca, M., Encarnação, S., \& Justino, E. (2014). Shrinking Higher Education Systems. In G. Goastellec, \& F. Picard (Eds.). Higher Education in Societies. A multi scale perspective (pp. 127-147). Rotterdam: Sense. ISBN 978-94-6209-744-5

Garrido, A. (2008). A Universidade e o Estado Novo: de "corporação orgânica" do regime a território de dissidência social. Revista Crítica de Ciências Sociais, 81, 133-153.

Gomes, A. S. (1964). O desenvolvimento socio-económico e a Educação. Análise Social, II(7-8), 652-670.

Governo de Portugal (1974-2015). Programas dos Governos Provisórios e Programas dos Governos Constitucionais. (26 Programas).

Guerra, J. P. M., \& Nunes, A. S. (1969). A crise da Universidade em Portugal: reflexões e sugestões. Análise Social, VII(25-26), 5-49.

Gumport, P. (2005). The organization of knowledge: imperatives for continuity and change in higher education. In I. Bleiklie, \& M. Henkel (Eds.), Governing Knowledge (pp. 113-132). Dordrecht: Springer. ISBN-10 1-40203489-X / ISBN-13 978-1-4020-3489-3

Guri-Rosenblit, S., Sebková, H., \& Teichler, U. (2007). Massification and diversity of higher education systems: interplay of complex dimensions. Higher Education Policy, 20, 373-389. 
Heywood, A. (2007). Politics. Basingstoke: Palgrave MacMillan. ISBN 978-0230-52497-2

Huntington, S. P. (1991). Democracy's third wave. Journal of Democracy, 2(2), $12-34$.

Jakobi, A. P. (2011). Political parties and the institutionalization of education: a comparative analysis of party manifestos. Comparative Education Review, 55(2), 189-209.

Jalali, C. (2003). A Investigação do Comportamento Eleitoral em Portugal: História e Perspectivas Futuras. Análise Social, XXXVIII(167), 545-572.

Jungblut, J. (2014). Partisan Politics in higher education policy. In Gaële Goastellec \& France Picard (Ed.s). Higher education in societies. A multi scale perspective. (pp. 87-111). Rotterdam: Sense Publishers. ISBN 97894-6209-746-9

Knutsen, O. R. (1998). Expert Judgements of The Left-Right Location of Political Parties: A Comparative Longitudinal Study. West European Politics, 21(2), 63-94.

Kogan, M. (1997). Diversification in higher education: differences and commonalities. Minerva, 35, 47-62.

Leuven / Lovain-la-Neuve Communiqué (2009). Bologna Follow-Up Group. Available at: http://www.ehea.info/pid34363/ministerial-declarations-and-communiques.html

Lisbon European Council - Presidency Conclusions (2000). Lisbon Strategy. European Council.

Lobo, M. C. (2000). Governos Partidários numa Democracia Recente: Portugal, 1976-1995. Análise Social, XXXV, 147-174.

London Communiqué (2007). Bologna Follow-Up Group. Available at: http:// www.ehea.info/pid34363/ministerial-declarations-and-communiques.html López-Santana, M. (2006). The domestic implications of European soft law: framing and transmitting change in employment policy. Journal of European Public Policy, 13(4), 481-499.

Machado, M. L., Ferreira, J. B., Santiago, R., \& Taylor, J.S. (2008). Reframing the Non-University Sector in Europe: Convergence or Diversity? In J. S. 
Taylor, J. B. Ferreira, M. L. Machado, \& R. Santiago (Eds.), Non-University higher education in Europe (pp. 245-260). Dordrecht: Springer. ISBN 978-1- 4020-8334-1

Magna Charta Universitatum (1988). Available at: http://www.magnacharta.org/ resources/files/the-magna-charta/english

Martins, C. M. A. (1968). Alguns aspectos do Ensino em Portugal. Análise Social, VI(20-21), 57-80.

Merkel, W., \& Petring, A. (2007). Social democracy in power: explaining the capacity to reform. Zeitschrift für Vergleichende Politikwissenschaft, 1(1),125-145.

Meyer, J. W., Rowan, B. (1977). Formal Structure as Myth and Ceremony. American Journal of Sociology, 83(2), 340-363.

Nunes, A. S. (1966). Para a reforma da universidade: um importante debate em frança. Análise Social, IV(16), 684-696.

Nunes, A. S. (1968). O sistema universitário em Portugal: alguns mecanismos, efeitos e perspectivas do seu funcionamento. Análise Social, VI(22-2324), 386-474.

Nunes, A. S. (1970). A universidade no sistema social português - uma primeira abordagem. Análise Social, VIII(32), 646-707.

Organisation for Economic Cooperation and Development (1974). Towards mass higher education - Issues and dilemmas. Conference on Future Structures of Post-Secondary Education. Paris: OECD.

Pennings, P. (1999). European social democracy between planning and market: a comparative exploration of trends and variations. Journal of European Public Policy, December, 743-756.

Pordata - Base de Dados Portugal Contemporâneo. Fundação Francisco Manuel dos Santos. Available at: http://www.pordata.pt/

Prague Communiqué (2001). Bologna Follow-Up Group. Available at: http:// www.ehea.info/pid34363/ministerial-declarations-and-communiques.html Rocha, M. (1968). A Educação Permanente. Análise Social, VI(20-21), 43-56.

Sauer, P., \& Zagler, M. (2014) (In)equality in education and economic development. Review of Income and Wealth. 60(S2), S353-379. Doi: 10.1111/ roiw.12142 
Scott, P. (1995). The meanings of mass higher education. Buckingham: SRHE and Open University Press. ISBN 0-335-19443-5

Sorbonne Declaration (1998). Joint Declaration on harmonisation of the architecture of the European higher education system. Available at: http:// www.ehea.info/pid34363/ministerial-declarations-and-communiques.html Sousa, A. (1968). Algumas reflexões sobre a democratização do Ensino Superior. Análise Social, VI (20-21), 248-253.

Teichler, U. (2004). The changing debate on internationalization of higher education. Higher Education, 48, 5-26.

Teichler, U. (2008). Diversification? Trends and explanations of the shape and size of higher education. Higher Education, 56, 349-379. DOI 10.1007/ s10734-008-9122-8

Teixeira, P. N., Rocha, V., Biscaia, R., \& Cardoso, M. F. (2012). Competition and diversity in higher education: an empirical approach to specialization patterns of Portuguese institutions. Higher Education, 63, 337-352. DOI 10.1007/s10734-011-9444-9

Torgal, L. R. (1999). A Universidade e o Estado Novo. O Caso de Coimbra. 19261961. Coimbra: Minerva. ISBN 972-8318-59-6

Triventi, M. (2014). Higher education regimes: an empirical classification of higher education systems and its relationship with student accessibility. Quality \& Quantity, 48(3), 1685-1703.

União Europeia (2000). Conclusões da Presidência do Conselho Europeu de Lisboa. Lisboa. Available at: https://infoeuropa.eurocid.pt/registo/000003888/documento/0001/

Vaira, M (2004). Globalization and Higher Education Organizational Change: A Framework for Analysis. Higher Education, 48, 483-510.

World Bank (1971). Education - Sector Working Paper. Washigton D.C.: World Bank.

World Bank (1974). Education - Sector Working Paper. Washigton D.C.: World Bank.

Yerevan Communiqué (2015). Bologna Follow-Up Group. Available at: http:// www.ehea.info/pid34363/ministerial-declarations-and-communiques.html 
Zha, Q. (2009). Diversification or homogenization in higher education: a global allomorphism perspective. Higher Education in Europe, 34(3-4), 459-479. Zomer, A., \& Benneworth, P. (2011). The rise of the university's third mission. In J. Enders, H.F. de Boer, \& D.F. Westerheijden (Eds.), Reform of Higher Education in Europe (pp. 81-101). 